\title{
WILLINGNESS TO PAY BY USING TRAVEL COST METHOD IN CHITWAN NATIONAL PARK, NEPAL
}

\author{
M. Aryal ${ }^{1}$, J.P. Dutta ${ }^{2}$, P.P Regmi ${ }^{1}$ and K.R. Pandey ${ }^{2}$ \\ ${ }^{1}$ Institute of Agriculture and Animal Sciences, Tribhuvan University, Nepal \\ ${ }^{2}$ Agriculture and Forestry University, Chitwan, Nepal
}

\begin{abstract}
This study assessed the impact of tourism and willingness to pay by foreigners in Chitwan National Park of Chitwan district during the year 2007-2008. Eighty tourists were selected randomly to evaluate the recreational value of Chitwan National Park to protect the biodiversity of buffer zone area in Chitwan National Park. The tourism created the local employment opportunities to local people but it was unplanned and location specific. Since the program has focused in both community development and conservation awareness activities however, the study showed that only public infrastructure development was emphasized instead of sensitizing the members towards the conservation issues of protected areas. The study examined how much Park visitors were willing to pay to visit the Park. Annual benefits from the Park were considerable - the total annual consumer surplus obtained from recreation in the Park was approximately USD 233 million. Various factors influence the visitors like travel cost, household income, and the quality of the Park. Improvements in quality of the Park were likely to increase recreational benefits.
\end{abstract}

Keywords: Tourism, Buffer Zone, Willingness to Pay, Biodiversity

\section{INTRODUCTION}

Ecotourism, also known as ecological tourism, is a form of tourism that appeals to the ecologically and socially conscious individuals. Generally speaking, ecotourism focuses on volunteering, personal growth, and learning new ways to live on the planet; typically involving travel to destinations where flora, fauna, and cultural heritage are the primary attractions. Responsible ecotourism includes programs that minimize the negative aspects of conventional tourism on the environment, and enhance the cultural integrity of local people. Therefore, in addition to evaluating environmental and cultural factors, an integral part of ecotourism is in the promotion of recycling, energy efficiency, water conservation, and creation of economic opportunities for the local communities.

Declaration of the buffer zone of Chitwan National Park (CNP) has given both opportunities and challenges to the park managers to promote ecotourism in the buffer zone. Especially, since the buffer zone encompasses tourist hot spots like Sauraha, where almost all hotels and lodges are operating park related tourism business, appropriate interventions could bring out desirable changes (DFRS, 2001). About 90 percent of the total revenue of the CNP is due to tourism activities and the amount is growing annually by 22.5 percent. Tourism in Chitwan must benefit local communities while balancing the requirement of biodiversity conservation in a national park setting and growth in wild life tourism.

Table 1: Trend of tourist visiting Nepal (2057/5/-2064/65)

\begin{tabular}{|l|l|l|l|l|l|l|l|l|}
\hline Years & $2057 / 58$ & $2058 / 59$ & $2059 / 60$ & $2060 / 61$ & $2061 / 62$ & $2062 / 63$ & $2063 / 64$ & $2064 / 65$ \\
\hline Nepali & 26457 & 15308 & 12586 & 10826 & 18019 & 25000 & 24690 & 20025 \\
\hline Foreign & 67195 & 38014 & 29349 & 40096 & 38006 & 45056 & 48921 & 80100 \\
\hline SAARC & 12602 & 4995 & 6986 & 6954 & 4100 & 2000 & 5475 & 10000 \\
\hline Total & 106254 & 58317 & 48921 & 57876 & 60125 & 72056 & 79086 & 110125 \\
\hline
\end{tabular}

Source: Chitwan National Park Bulletin, 2007/08. 
Willingness to Pay (WTP) is defined as maximum amount of money that may be contributed by an individual to equalize a utility change. The technique is based on the principle that the maximum amount of money an individual is willing to pay for a commodity is an indicator of the value to him/ her of that commodity. Khan (2004) estimated the benefits of establishing and managing the Margalla Hills National Park near Islamabad using Individual Travel Cost Method (TCM). The total annual consumer surplus obtained from recreation in the Park was approximately Pakistani Rs. 23 million (USD 0.4 million). Improvements in the quality of the Park were likely to increase recreational benefits by a significant 39\%. The study recommended that a Park entrance fee of Rs. 20 per person to be introduced, which could be utilized for Park management. This would generate nearly Rs. 11 million in revenues annually, a sizable amount of money that represents about $4 \%$ of the annual budget allocated to the environment sector in Pakistan.

Khan (2004) enlisted some of the important works done on economic evaluation of protected areas using TCM. Chase et al. (1998 cited in Khan, 2004) studied ecotourism demand and the differential pricing of National Park access in Costa Rica. The study presents conceptual framework and an empirical analysis of the impacts of introducing a differential entrance fee policy at three national Parks in Costa Rica. Similarly, Grandstaff and Dixon (1986 cited in Khan, 2004) used the zonal TCM to valuate the Lumpinee Park in Thailand. The consumer surplus of Lumpinee Park was found to be 132 million baht. Kaosa-ard et al. (1995 cited in Khan, 2004) also used TCM to measure the Khao Yai National Park use value. The TCM estimates showed a direct benefit of 1,420 baht per visit, of which 870 baht is the consumer surplus.

\section{METHODOLOGY}

A total of 80 tourists were selected randomly for the interview to collect information for the calculation of willingness to pay (WTP), recreational value of Chitwan National Park, biodiversity conservation and recreational benefits.

Travel Cost Method (TCM) was used to calculate WTP by a particular visitor. The TCM enables an assessment of individual preferences for the consumption of non-market goods. It uses the cost of traveling to a non-priced recreation site in order to infer recreational benefits provided by the site, the effect of explanatory variable on WTP to visit the area was studied through the use of Regression Model. According to Pearce et al., (1994) the total economic value consists of different values which can be seen in equation:

Total economic value $=$ Existence value + Bequest value + Indirect use value + Option value + Direct use value

The indirect use value could in the case of Chitwan National Park be the shelter that it gives to all life in the Park, whereas the direct use value would be the recreation gained by visiting the Park. Optional value is a value that compares current benefits of the Park with future benefits. The bequest is a value that represents the future use of Park for future generations. Existence value could in the case of Chitwan National Park be the value that represents preserving biodiversity inside the Park. The travel cost method applied surveys for people visiting a non-priced site for recreation; the data collected from the surveys was data about their number of visits to the site and their different costs in reaching the site. This cost was used to derive the demand function for the site. It was expected that the higher the cost of reaching a site was, the lower was the amount of visits to the site will be made, ceteris paribus. Therefore, the demand curve was expected to be negatively sloped.

$$
\mathrm{V}=\mathrm{f}(\mathrm{P}, \mathrm{S})
$$

Where, $\mathrm{V}=$ Visit rate, $\quad \mathrm{P}=$ Cost of travel to the site

$\mathrm{S}=$ Vector of travel cost to substitute sites 
The individual travel cost methods trip generating function can according to Garrod and Willis (1999) be defined as:

$$
\mathrm{V}_{\mathrm{ij}}=f\left(\mathrm{P}_{\mathrm{ij}} \mathrm{T}_{\mathrm{ij}}, \mathrm{Q}_{\mathrm{i}}, \mathrm{S}_{\mathrm{j}}, \mathrm{Y}_{\mathrm{i}}\right)
$$

Where, $\mathrm{Vij}=$ Number of visits made by individual $\mathrm{i}$ to site $\mathrm{j}$

Pij $=$ Travel cost incurred by individual $\mathrm{i}$ when visiting site $\mathrm{j}$

Tij $=$ Time cost incurred by individual $\mathrm{i}$ when visiting site $\mathrm{j}$

$\mathrm{Q} i=$ Vector of perceived qualities for the individual i

$\mathrm{Sj}=$ Vector of the characteristics of available substitute sites

$\mathrm{Yi}=$ Household income of individual $\mathrm{i}$

With this trip generating function the demand for visits to the Park can be derived and from the demand, the consumer surplus can be derived. The most basic application of the travel cost method would only look at what people actually pay for reaching a site, leaving out other important factors that may influence the visitors decision on visiting a site, the most important ones will now be explained (Garrod and Willis, 1999). When travelling to a site time was spent on reaching the site, time which instead could have been used for other activities, such as work. But most people are not able to freely choose how many hours to work, as this was decided in their contracts. So adding the entire wage rate might cause an overestimation of the recreational value. There is uncertainty in the economic literature if the wage rate should be used or not, and if it's used how much of the wage rate that should be added. Previous studies by Cesario (1976) suggest that one third of the hourly wage rate should be calculated for the time cost.

For visitors travelling a longer distance to visit the site it is more likely that their entire trip has many destinations, and therefore if assigning the entire travel cost to the specific site would cause an overestimation of the site's recreational value (Garrod and Willis, 1999). This was known as the problem with multiple visit journeys. If there is a lack of substitute sites an overestimation of willingness to pay may occur. A site for recreation that has a lack of substitute sites may get visitors to choose to visit this site just because there is a lack of substitute sites for recreation; therefore their willingness to pay is lower than what they are actually paying to visit the site (Turner et al., 1994). Congestion could be a problem for the application of the travel cost method. Congestion of a Park is that total amount of visitors reaches a level where the Park is not able to accept any more visitors due to supply limitations. For example if there is a finite amount of visitors that can go on a boat ride in the Park and the boat is full, then the demand exceeds the supply. The result of the demand not being satisfied could results in an underestimation of the demand function, this leading to an underestimated consumer surplus (Garrod and Willis, 1999).

\section{Model for the Consumer Surplus}

The consumer surplus is the difference between what an individual is willing to pay at most and what was actually paid for the use of a resource (Pearce and Turner, 1999). The consumer surplus was used as a monetary estimate for the recreational value of the National Park. The consumer surplus can be derived by first creating a trip generating function, in this case:

$$
V_{i j}=f\left(P_{i j}, T_{i j}, Q_{i}, S_{j}, Y_{i}\right)
$$

So that the consumer demand for the site can be derived. This relationship is expected to be negative, so that the number of visits decreases as travelling cost increase.

According to Garrod and Willis (1999), consumer surplus can be defined as:

Consumer surplus $=-\mathrm{V} / \mathrm{P}_{\mathrm{ij}}$

Equation 3 estimates the average consumer surplus. To be able to get the aggregated consumer surplus the average consumer surplus has to be multiplied by the total amount of visitors to the site 
during a specific time. The total aggregated consumer surplus was used as a measurement of the total recreational value for the national Park. The trip generating function was transformed into a function that can be used in a simple regression model:

$$
V_{i j}=\beta_{0}+\beta_{1} X_{1}+\beta_{2} X_{2}+\beta_{3} X_{3}+\beta_{4} X_{4}+\beta_{5} X_{5}+\beta_{6} X_{6}
$$

Where, $V_{i j}=$ Number of visits by a tourist

$$
\begin{array}{lll}
X_{1}=\text { Travel cost } & X_{2}=\text { Income } & X_{3}=\text { Age } \\
X_{4}=\text { Nationality } & X_{5}=\text { Gender } & X_{6}=\text { Substitute site } \\
\beta_{0}, \beta_{1} \ldots \beta_{6}=\text { coefficient to be estimated } &
\end{array}
$$

Travel to a site takes time and the time spent on travelling could instead have been used for other activities, such as work. There is uncertainty in the economic literature of how this opportunity cost should be calculated. Therefore two different ways were tested; one where time cost depends on the hourly wage rate and another where the time cost depends on the travelling experience.

When calculating the time cost depending on hourly wage rate the amount of hours worked per month needs to be found, this since it is the unit used in the questionnaire for stated income. According to the International Labour Organization (2007) the standard amount of working hours per week was 48. By calculations, the number of working hours per month was assumed to be 208 in this study. Adding the entire hourly wage rate might cause an overestimation since most people are constrained to working hours as decided in their contracts. Previous studies by Cesario (1976) suggest that one third of the hourly wage rate should be calculated for the time cost (Hanley, 1993). By applying this it would make the time cost look like this:

Time cost $=\frac{[\mathrm{HH} \text { monthly income/ Earning members of } \mathrm{HH}] / \text { Work hour per month }}{3}$

By using following way of how to calculate the time cost gives the following travel cost function: $\mathrm{TC}=($ Travel cost + Travel time $*$ Time cost $) *$ Importance of the national Park

In the survey an approximation was made by the respondents on how much of the travel cost that should be related to the trip to the national Park. The value stated in percentage was used in calculating both the travel cost to the national Park and the travel cost to Nepal.

The respondents were asked to state their monthly household income in their currency. The income variable was first recalculated to USD and then divided by the number of earning members of the household.

Dummy variables can be used as a way of introducing variables of qualitative nature into the regression model. The advantage of doing this was that the results can show if the qualitative variables has any statistical significance for the chosen model.

The substitute site variable was given the value 1 if the respondent stated that they had a substitute site to visit if they did not visit Chitwan National Park and the value 0 if they didn't state a substitute site for the Park. The gender variable was given the value 1 if the respondent stated that they were male and 0 if they were female. A possible bias could be that while some of the respondents filled in that a male had responded to the survey some of the results were from females.

The nationality variable was given the value 1 when the respondent stated that their nationality was other than Europe, and when the respondent stated that their nationality was Europe the variable was given the value 0 . 


\section{RESULT AND DISCUSSIONS}

Trend of tourist and Visitor's characteristics in Chitwan National Park

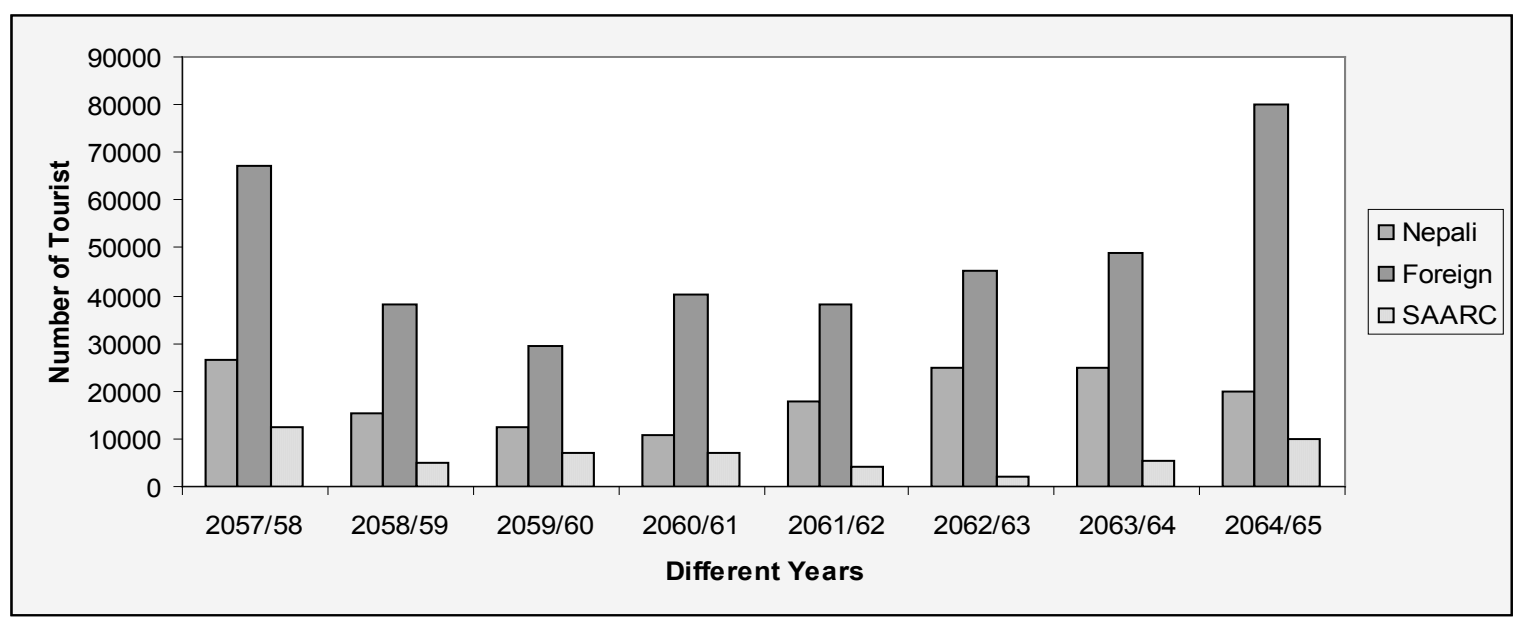

The majority of the tourist visiting the national park were Europeans (43.8\%) followed by North Americans (28.7\%), Asians (16\%), and South American (3.8\%). About 52.5\% of the visitors surveyed were male and the rest were females (47.5\%). Visitors from African and North America were mostly females (Table 2).

Table 2: Number and Percentage of visitors' Nationality and sex composition (2008)

\begin{tabular}{llll}
\hline Nationality & Male & Female & Total \\
\hline Europe & $19(45.2)$ & $16(42.1)$ & $35(43.8)$ \\
North America & $11(26.2)$ & $12(31.6)$ & $23(28.7)$ \\
Asia & $9(21.4)$ & $7(18.4)$ & $16(16)$ \\
South America & $2(4.8)$ & $1(2.6)$ & $3(3.8)$ \\
Africa & $1(2.4)$ & $2(5.3)$ & $3(3.7)$ \\
\hline Total & $42(52.5)$ & $38(47.5)$ & $80(100)$ \\
\hline
\end{tabular}

Source: Field Survey, 2008.

Figures in parentheses indicate Percentage.

About $31.2 \%$ of the visitors were $26-40$ age groups. $27.5 \%$ were less than 25 yrs of age while those $41-55$ years were about $18.8 \%$ and above 56 years were $22.5 \%$ (Table 3 ).

Table 3: Age distribution of visitors' visiting the Chitwan National Park (2008)

\begin{tabular}{llll}
\hline Age(Years) & Male & Female & Total \\
\hline$\leq 25$ & $12(28.6)$ & $10(26.3)$ & $22(27.5)$ \\
$26-40$ & $13(31)$ & $12(31.6)$ & $25(31.2)$ \\
$41-55$ & $8(19)$ & $7(18.4)$ & $15(18.8)$ \\
$\geq 56$ & $9(21.4)$ & $9(23.7)$ & $18(22.5)$ \\
\hline
\end{tabular}

Source: Field Survey, 2008.

Figures in parentheses indicate Percentage.

The majority (66.3\%) of them were earning less than USD 30,000 annually, 25\% belonged to annual income of USD 30,001-45,000 annual income (Table 4). 
Table 4: Annual income of sampled tourist visiting the Chitwan National Park (2008)

\begin{tabular}{llll}
\hline Annual Income(USD) & Male & Female & Total \\
\hline$\leq 15,000$ & $13(31)$ & $11(28.9)$ & $24(30)$ \\
$15,001-30,000$ & $16(38.1)$ & $13(34.2)$ & $29(36.3)$ \\
$30,001-45,000$ & $10(23.8)$ & $10(26.3)$ & $20(25)$ \\
$45,001-75,000$ & $3(7.1)$ & $4(10.5)$ & $7(8.7)$ \\
\hline
\end{tabular}

Source: Field Survey, 2008.

Figures in parentheses indicate Percentage.

Service was the major occupation for majority of the visitors (46.3\%) followed by business $(20 \%)$ and student (16.3\%). Those falling in the lower income brackets were mostly students (Table 5).

Table 5: Occupation of tourist visiting the Chitwan National Park (2008)

\begin{tabular}{llllll}
\hline Nationality & Service & Business & Farmer & Student & Others \\
\hline Europe & $20(54.1)$ & $6(37.5)$ & - & $5(38.5)$ & $4(33.3)$ \\
North America & $9(24.3)$ & $5(31.3)$ & $2(100)$ & $3(23.1)$ & $4(33.3)$ \\
Asia & $6(16.2)$ & $4(25)$ & - & $4(30.8)$ & $2(16.7)$ \\
South America & $1(2.7)$ & $1(6.3)$ & - & - & $1(8.3)$ \\
Africa & $1(2.7)$ & - & - & $1(7.7)$ & $1(8.4)$ \\
\hline Total & $37(46.3)$ & $16(20)$ & $2(2.5)$ & $13(16.3)$ & $12(15)$ \\
\hline
\end{tabular}

Source: Field Survey, 2008.

Figures in parentheses indicate Percentage.

\section{Means of Travel}

A large portion of the visitors (51.3\%) stated bus as their chief means of traveling to Chitwan. $28.8 \%$ used private vehicles and only a few opted for the air service to Chitwan. Those who travelled by air mostly preferred staying in expensive hotels. Most of those travelling to Chitwan by bus stayed in low budget hotels (Table 6).

Table 6: Means of travel used by tourist to visit the Chitwan National Park (2008)

\begin{tabular}{lllll}
\hline Nationality & Bus & Plane & Private Vehicles & Others \\
\hline Europe & $17(41.5)$ & $4(57.1)$ & $12(52.2)$ & $2(22.2)$ \\
North America & $12(29.3)$ & $3(42.8)$ & $6(26.1)$ & $2(22.2)$ \\
Asia & $8(19.5)$ & - & $5(21.7)$ & $3(33.3)$ \\
South America & $2(4.9)$ & - & - & $1(11.1)$ \\
Africa & $2(4.9)$ & - & - & $1(11.2)$ \\
\hline Total & $41(51.3)$ & $7(8.8)$ & $23(28.7)$ & $9(11.2)$ \\
\hline
\end{tabular}

Source: Field Survey, 2008.

Figures in parentheses indicate Percentage.

Table 7: Package tour and Average cost per package of tourist in Chitwan National Park

\begin{tabular}{llll}
\hline Nationality & Package tour & Other & Average cost per package(USD) \\
\hline Europe & $25(46.3)$ & $10(38.5)$ & 175 \\
North America & $15(27.8)$ & $8(30.8)$ & 160 \\
Asia & $10(18.5)$ & $6(23.1)$ & 100 \\
South America & $3(5.6)$ & - & 140 \\
Africa & $1(1.9)$ & $2(7.7)$ & 125 \\
\hline Total & $54(73.8)$ & $26(26.2)$ & 140 \\
\hline
\end{tabular}

Source: Field Survey, 2008.

Figures in parentheses indicate Percentage. 
About $73.8 \%$ tourist visited the Chitwan National Park in package through different travelling agencies and rest used individual tour to Chitwan National Park (Table 7). Average cost per package tour was found USD 140 for 3 days and 2 night including travel cost from Kathmandu to Chitwan National Park.

\section{Duration of stay}

A majority of the visitors stay $\leq 3$ days in Chitwan National Park (CNP). The average length of visitors stay in CNP was 3.27 days, whereas the average intended length of stay in Nepal was 24.88 days (Table 8). Only $13.1 \%$ of the visitor's total stay in Nepal is actually spent in Chitwan, indicating that most tourists coming to Nepal have other destination besides Chitwan National Park in Nepal. By nationality, the average length of stay in CNP was the highest for European group (3.89 days) followed by African (3.79 days). It was the lowest among Asian tourists (2.57).

Table 8: Average days spent in Chitwan and Nepal by tourist (2008)

\begin{tabular}{lll}
\hline Nationality & Average days in Chitwan & Average days in Nepal \\
\hline Europe & $3.89 \pm 1.97$ & $33.1 \pm 35.6$ \\
North America & $2.79 \pm 1.19$ & $41.1 \pm 59.2$ \\
Asia & $2.57 \pm 0.78$ & $12.5 \pm 6.9$ \\
South America & $3.25 \pm 3.26$ & $26.3 \pm 20.34$ \\
Africa & $3.79 \pm 1.12$ & $11.4 \pm 2.4$ \\
\hline Total & $3.27 \pm 1.66$ & $24.88 \pm 25.38$ \\
\hline
\end{tabular}

Source: Field Survey, 2008.

Figures in parentheses indicate Percentage.

Visitor's willingness to pay a higher entrance fee Information on visitor's willingness to pay provides a realistic basis for setting visitor entrance fees. Asked if they were willing to pay more for visiting the national Park under the current level of services, about $75 \%$ of the visitors surveyed responded affirmatively. This willingness to pay higher entrance fee was relatively greater among European (48.3\%) and North American (33.3\%) visitors, who were mostly in the 26-55 yrs age group and belonged to middle income level (USD 15,000 to 45,000). Willingness to pay a higher entrance fee for the current services was found to be generally higher among those who stayed relatively longer periods ( 2 to $4 \mathrm{wks}$ ) in Nepal.

Table 9: Visitors reporting their willingness to pay more to visit Chitwan National Park

\begin{tabular}{lll}
\hline Nationality & Yes & No \\
\hline Europe & $29(48.3)$ & $6(30)$ \\
North America & $20(33.3)$ & $3(15)$ \\
Asia & $9(15)$ & $7(35)$ \\
South America & $1(1.7)$ & $2(10)$ \\
Africa & $1(1.7)$ & $2(10)$ \\
\hline Total & $60(75)$ & $20(25)$ \\
\hline
\end{tabular}

Source: Field Survey, 2008.

Figures in parentheses indicate Percentage.

Information on the level of the incremental fee to the Park was also obtained form the visitors. The average incremental fee based on the sample was USD 7.86. There was a considerable variation in the maximum entrance fee by type of tourists. Large number of Europeans and North Americans 
were willing to pay about the average of USD 8 as incremental fee. The results indicated that there is some potential for increasing the park entrance fee without deterring visitors and keeping the level of services to a desired level.

The willingness to pay incremental fee expressed by visitors also varied with the quality of guide services. For example those who stated the guide services to be excellent expressed the need for higher entrance fee than those who found guide services to be generally poor. This reflects the need for enhancing the quality of guide services through proper training. About $45 \%$ of the visitors, mostly Europeans indicated that payment of higher entrance fee should be influenced by the extent to which these resources were used for local development activities.

Table 10: Maximum Incremental Park entrance fee

\begin{tabular}{ll}
\hline Nationality & Average \\
\hline Europe & $6.7 \pm 3.1$ \\
North America & $7.1 \pm 3.6$ \\
Asia & $9.2 \pm 2.1$ \\
South America & $8.9 \pm 1.5$ \\
Africa & $7.4 \pm 3.8$ \\
\hline Total & $7.86 \pm 4.3$ \\
\hline
\end{tabular}

\section{Results from the Regression Analysis}

There are difficulties in deriving demand curves for intangible services such as those enjoyed from national parks; since the different types of benefits that national parks can offer varies significantly. For many goods and services traded in the market, deriving demand curves are fairly straight forward, but such is not the case for intangible benefits as in the case of national parks. Services can be simultaneously enjoyed by many and often it is not possible to exclude those who are willing to pay to enjoy services (to a certain point). Such services posses the characteristics of public goods. However, one faces both conceptual and practical problems in assigning monetary value for intangible like recreational demand is the main component of demand two methods are available to estimate the demand curve for recreation.

Table 11: Results from the regression analysis of the trip generating function

$\begin{array}{lll}\text { Variables } & \text { Coefficients } & \text { T-values } \\ \text { Constant } & -0.07 & -0.347 \\ \text { Travel cost } & -0.8 * 10^{-3} & -1.627 \\ \text { Age } & 0.02 & 2.750 \\ \text { Gender } & 0.20 & 0.742 \\ \text { Nationality } & -0.12 * 10^{-2} & -0.009 \\ \text { Income } & 0.57 * 10^{-4} & 0.418 \\ \text { Substitute } & -0.18 & -1.190\end{array}$

$\mathbf{R}^{2}=\mathbf{0 . 3 8 4}$

The $\mathrm{R}^{2}$ coefficient explains to what extent the included variables can explain the variation in the number of visits made. The $\mathrm{R}^{2}$ value of the regression analysis was estimated to $38.4 \%$. Compared to similar studies this value can be seen as a low value, and this would imply that the relationship between the number of trips made to the park and the included variables is low. 
And F-test to test the goodness of fit was performed with the F-value of 1.63 and the test could not reject the null hypothesis at both one and 5\% significant level. This would imply that the slope variables can not explain the number of visits made. The null hypothesis was that all slope variables included in the model is equal to zero.

The income variable has the value of $0.57 * 10^{-4}$; this means that the higher the household income is the more visits you will do, ceteris paribus, which is correct according to economic theory. But since the value is close to zero it would imply that a change in income has little effect on how many visits that are made to the national park.

The travel cost variable showed a negative value of $-0.8^{*} 10^{-3}$, according to the theoretical framework this seems correct, that the number of visits decrease as the travel cost increase. But since the value is close to zero it would imply that a change in travel cost has little effect on how many visits that are made to the national park.

One of the dummy variables was the age variable which has the value 0.02 , this would imply that older people makes more visits. Also gender was used as a dummy variable, the results showed that it has a value of 0.20 ; meaning that if the respondent is a male more visits will be made than a female respondent would have made. The respondents nationality was also used as a dummy variable, the results from this variable was that if the respondent is a European they will make $-0.12^{*} 10^{-2}$ less visits than others, which seems correct since usually they have higher travel cost and would not make as many visits.

To test whether the coefficients are statistically significant to the number of visits a T-test was performed. The results from the T-test showed that the only coefficient that was statistically significant is the age coefficient. This does not mean that the other coefficient doesn't have an effect on visits made, but only that the model can't prove it.

As expected, the travel cost has a negative relationship to the number of visits made to the park and income has a positive relationship to the number of visits made. But the model used to explain the number of trips made to the park seems to be insufficient. This because of the values of the travel cost coefficient and the income coefficient were close to zero and these two coefficients should be the two coefficients that has the biggest effect on how many trips that are made to the park. Since this is not the case the model failed to explain the variations in visits made to the park.

\section{The Consumer Surplus}

As described above the individual average consumer surplus could, according to Garrod and Willis (1999), be calculated as in equation (3).

Consumer surplus $=$ Average visits/ Travel cost

Applying the results in this model gave: $2112.5=1.69 /\left(-0.8 * 10^{-3}\right)$

Aggregated consumer surplus $=1,10,125 * 2112.5=\mathrm{USD} 23,26,39,062.5$

The aggregated consumer surplus for the national Park was calculated to USD 233 million, as seen in equation 9. This value seems high, and a probable cause for the high consumer surplus could be the low travel cost coefficient which might be because the survey of foreigners only. The consumer surplus was calculated by dividing the average number of visits made to the Park by the travel cost coefficient. A low travel cost coefficient resulted in a high consumer surplus. Even though this value seems high it is possible that it is underestimated since the chosen method only captured the recreational value, and no other parts of the total economic value. In the construction of the survey some of the problems with the travel cost method have been approached, but since we obtained a high estimate for the consumer surplus it seems likely that some of the problems still remains. The 
consumer surplus has a high value and reason for this may be that the consumer surplus is highly sensitive to the specifications in the model which is according to Garrod and Willis (1999)

\section{SUMMARY AND CONCLUSIONS}

The majority of the tourists were from Europe (43.8\%) and in terms of gender, $52.5 \%$ were male. It showed that $31.2 \%$ of respondents were $26-40$ yrs age groups. The majority $(66.3 \%)$ of them were earning less than USD 30,000 annually. Service was the major occupation for $46.3 \%$ visitors and $51.3 \%$ stated bus as the chief means of travelling to Chitwan. Most of the visitors (73.8\%) stated that they visited the Park in package than individuals. Average cost per package tour was found about USD 140 for 3 days and 2 nights. Most of the visitors stayed 3.27 days in Chitwan of 24.88 days in Nepal.

Aggregated consumer surplus was found USD 233 million during 2007/08. In this study, the individual travel cost model was used to analyze and measure the recreational value of the CNP. This analysis showed that if the quality of CNP is improved, it will attract more visitors and, in turn, generate greater revenue.

\section{ACKNOWLEDGEMENT}

I would like to thank South Asia Network of Economic Research Institute (SANEI)-Pakistan for financial support.

\section{REFRENCES CITED}

Abala, D. O. 1987. A Theoretical and Empirical Investigation of the Willingness to Pay for Recreational Services: A Case Study of Nairobi National Park. Eastern Economic Review, 3: 271-92.

Chase, L., D. Lee., W. Schulze and D. Anderson. 1998. Ecotourism Demand and Differential Pricing of National Park Access in Costa Rica. Land Economics, 74 (4): 466-482.

Garrod, G. and K. G. Willis. 1999. Economic Valuation of the Environment: Methods and Case Studies, Cheltenham, UK and Northampton, MA, USA: Edward Elgar.

Grandstaff, S. and J. A. Dixon. 1986. Evaluation of Lumpinee Park in Bangkok, Thailand', in J.A. Dixon and M.M. Hufschmidt (eds). Economic Valuation Techniques for the Environment: A Case Study Workbook. Baltimore: Johns Hopkins University Press.

Khan, H. 2004. Demand for Eco-tourism: Estimation of Recreational Benefits from the Margalla Hill National Park in Northern Pakistan. Working Paper No. 5-04. SANDEE, Kathmandu, Nepal.

Lindberg, K. and R. L. Johnson. 1994. Estimating Demand for Ecotourism Sites in Developing Nations, Trends, 31: 10-15.

McConnell, K. E. 1992. On-site Time in the Demand for Recreation. American Journal of Agricultural Economics, 74: 918-25. 